\title{
Effect of phosphate-bonded investments on titanium reaction layer and crown fit
}

\section{Sicknan Soares da Rocha ${ }^{(a)}$ \\ Fabiane Nogueira(b) \\ Anelise Rodolfo Ferreira Pieralini(b) \\ Ricardo Faria Ribeiro(c) \\ Gelson Luis Adabo ${ }^{(d)}$}

(a) Professor of Dental Clinic, Department of Prevention and Oral Rehabilitation, Federa University of Goiás, Goiânia, GO, Brazil.

(b) Graduate student; (d) Professor of Dental Materials - Department of Dental Materials and Prosthodontics, Faculdade de Odontologia de Araraquara, Unesp - Univ Estadual Paulista, Araraquara, SP, Brazil.

(c) Professor of Prosthodontics, Department of Dental Materials and Prosthodontics, School of Dentistry of Ribeirão Preto, University of São Paulo, Ribeirão Preto, SP, Brazil.

\section{Corresponding author:}

Gelson Luis Adabo

UNESP - Universidade Estadual Paulista

Departamento de Materiais Dentários e Prótese

Rua Humaitá, 1680

Araraquara - SP - Brazil

CEP: 14801-903

E-mail: adabo@foar.unesp.br

Received for publication on Jun 24, 2009 Accepted for publication on Mar 23, 2010

\begin{abstract}
This study analyzed the reaction layer and measured the marginal crown fit of cast titanium applied to different phosphate-bonded investments, prepared under the following conditions (liquid concentration/casting temperature): Rema Exakt (RE) - $100 \% / 237^{\circ} \mathrm{C}, 75 \% / 287^{\circ} \mathrm{C}$, Castorit Super C (CS) $-100 \% / 70^{\circ} \mathrm{C}, 75 \% / 141^{\circ} \mathrm{C}$ and Rematitan Plus (RP)$100 \% / 430^{\circ} \mathrm{C}$ (special to titanium cast, as the control group). The reaction layer was studied using the Vickers hardness test, and analyzed by two way ANOVA and Tukey's HSD tests $(\alpha=0.05)$. Digital photographs were taken of the crowns seated on the die, the misfit was measured using an image analysis system and One-way ANOVA, and Tukey's test was applied $(\alpha=0.05)$. The hardness decreased from the surface (601.17 VHN) to $150 \mu \mathrm{m}(204.03 \mathrm{VHN})$. The group CS $75 \% / 141^{\circ} \mathrm{C}$ presented higher hardness than the other groups, revealing higher surface contamination, but there were no differences among the groups at measurements deeper than $150 \mu \mathrm{m}$. The castings made with CS $-100 \% / 70^{\circ} \mathrm{C}$ presented the lowest levels of marginal misfit, followed by RE $-100 \% / 237^{\circ} \mathrm{C}$. The conventional investments CS $(100 \%)$ and RE $(100 \%)$ showed better marginal fit than RP, but the CS (75\%) had higher surface contamination.
\end{abstract}

Descriptors: Dental casting investment; Dental alloys; Titanium; Dental casting technique; Dental prosthesis.

\section{Introduction}

Titanium has been used for dental prosthesis frameworks because of its excellent biocompatibility, high corrosion resistance, low density, adequate mechanical properties and low cost. ${ }^{1-3}$ However, titanium has a high melting point $\left(1,720^{\circ} \mathrm{C}\right)$ and high chemical reactivity with oxygen and nitrogen (atmospheric air) as well as with other elements of the investment materials. ${ }^{4}$ Its extreme reactivity at high temperatures results in a contaminated surface layer ${ }^{5}$ that leads to a nonhomogeneous microstructure with consequent increase in hardness, brittleness, and susceptibility to corrosion. ${ }^{5,6}$

Silica-based phosphate-bonded investments exhibit a thermal expansion compatible with titanium casting shrinkage, ${ }^{7}$ but the silica is highly reactive at high temperatures. ${ }^{8}$ Other thermally more stable refractory oxide materials (calcium oxide, magnesium oxide and aluminum oxide) have been developed, but they have shown thermal expansion unable to compensate for the casting shrinkage of molten titanium. ${ }^{7}$

In 2007 Ferreira et al. ${ }^{9}$ measured the setting and thermal expansion 
of 3 phosphate-bonded investments: Rematitan Plus (specifically for titanium), Rema Exakt and Castorit Super C, using different special liquid concentrations. The heating temperature necessary to achieve an expansion equivalent to that of the Rematitan Plus (control group) at the temperature recommended by the manufacturer $\left(430^{\circ} \mathrm{C}\right)$ was determined for these investments. The Rema Exakt and Castorit Super $\mathrm{C}$ investments achieved expansion equivalent to that of Rematitan Plus $\left(430^{\circ} \mathrm{C}\right)$ at significantly lower temperatures.

The aim of this study was to evaluate the effect of these investments at the temperatures measured by Ferreira et al. ${ }^{9}$ (2007) on the marginal misfit and reaction layer of cast, commercially pure titanium crowns.

\section{Material and Method}

A steel die representing a full-crown preparation was made, measuring $6.0 \mathrm{~mm}$ long, $1.0 \mathrm{~mm}$ shoulder, $7.0 \mathrm{~mm}$ cervical diameter, $5.7 \mathrm{~mm}$ occlusal diameter and a 6-degree axial surface convergence angle. Forty impressions of the steel die were made with polyvinyl siloxane and poured with epoxy resin (Epo-Thin, Buehler UK Ltd., Coventry, West Midlands, England). The wax patterns of the crowns were made on each epoxy resin die. The labial surface on the epoxy die and wax pattern was marked with a thin line to ensure proper orientation of the crown casting. The sprued patterns were placed in a plastic casting ring (number 3; Dentaurum J. P. Winkelstroeter KG, Pforzheim, Baden-Württemberg, Germany).

Table 1 lists the studied metal and investments.

The Rematitan Plus investment (Dentaurum J. P. Winkelstroeter KG, Pforzheim, Baden-Württemberg, Germany) was mixed at $100 \%$ special liquid concentration and the casting temperature was $430^{\circ} \mathrm{C}$, in accordance with the manufacturer's instructions (control group).

The investments Rema Exakt (Dentaurum J. P. Winkelstroeter KG, Pforzheim, Baden-Württemberg, Germany) and Castorit Super C (Dentaurum J. P. Winkelstroeter KG, Pforzheim, Baden-Württemberg, Germany) were mixed in accordance with the manufacturer's instructions, using two different concentrations of special liquid (100\% and $75 \%)$. The investments were heated and cooled in an electric furnace, EDG 7000 (EDG Equipments, São Carlos, São Paulo, Brazil), in accordance with the manufacturer's recommendations, except for the final temperature. The casting temperatures were established in a previous study ${ }^{9}$ that measured the setting and thermal expansion of the Rematitan Plus, Rema Exakt and Castorit Super C. The study showed the Rematitan Plus has a total expansion of $0.86 \%$ at the temperature recommended by the manufacturer $\left(430^{\circ} \mathrm{C}\right)$, and the Rema Exakt and Castorit Super C prepared with $100 \%$ or $75 \%$ of special liquid concentration achieved expansion equivalent to that of the control group at the temperatures described in Table 2.

The investment molds were inserted into the Discovery Plasma Ar-arc vacuum-pressure casting machine (EDG Equipments, São Carlos, São Paulo, Brazil). For each casting, $14 \mathrm{~g}$ of CP Ti were used.

The castings $(\mathrm{n}=8)$ were carefully removed from the molds, scrubbed under running water, and cleaned in water using an ultrasonic cleaner (Ultrasonic Cleaner, Odontobras, Ribeirão Preto, São Paulo, Brazil). A cutting disc (Dentaurum J. P. Winkelstroeter KG, Pforzheim, Baden-Württemberg, Germany) was used to separate the crown from the sprue. The castings were cleaned in an aqueous solu-

Table 1 - Metal, investments, chemical composition and manufacturer.

\begin{tabular}{c|c|c|c}
\hline Material & Commercial Brand & Chemical composition (\%)* & Manufacturer \\
\hline \multirow{2}{*}{ Metal } & c.p. Ti 2 & $\mathrm{Ti}(99.56) ; \mathrm{Fe}(0.18) ; \mathrm{O}(0.15) ; \mathrm{C}(0.08) ; \mathrm{N}(0.02) ; \mathrm{H}(0.007)$ & RMI Company, Niles, Ohio, USA \\
\hline \multirow{3}{*}{ Investment } & Rematitan Plus (RP) & $\mathrm{SiO}_{2}(55-75) ; \mathrm{MgO}(10-30) ; \mathrm{Al}_{2} \mathrm{O}_{3}(10-25) ; \mathrm{NH}_{4} \mathrm{H}_{2} \mathrm{PO}_{4}(5-10)$ & \multirow{2}{*}{ Dentaurum, Pforzheim, Baden- } \\
\cline { 2 - 4 } & Rema Exakt (RE) & $\mathrm{SiO}_{2}(60-80) ; \mathrm{MgO}(10-30) ; \mathrm{NH}_{4} \mathrm{H}_{2} \mathrm{PO}_{4}(10-30) ; \mathrm{FeO}_{2}(0-1)$. & Wurttemberg, Germany \\
\cline { 2 - 4 } & Castorit Super C (CS) & $\mathrm{SiO}_{2}(60-80) ; \mathrm{NH}_{4} \mathrm{H}_{2} \mathrm{PO}_{4}(10-20) ; \mathrm{MgO}(6-19)$ & \\
\hline
\end{tabular}

* Information provided by the Manufacturer. 
Table 2 - Casting temperatures for the investment expansion equivalent to that of the Rematitan Plus (control group).

\begin{tabular}{c|c|c}
\hline Group & Materials and liquid concentration & $\begin{array}{c}\text { Casting } \\
\text { Temperature* }\end{array}$ \\
\hline 1 & RP mixed with $100 \%$ special liquid & $430^{\circ} \mathrm{C}$ \\
\hline 2 & RE mixed with $100 \%$ special liquid & $237^{\circ} \mathrm{C}$ \\
\hline 3 & RE mixed with $75 \%$ special liquid & $287^{\circ} \mathrm{C}$ \\
\hline 4 & $\mathrm{CS}$ mixed with $100 \%$ special liquid & $70^{\circ} \mathrm{C}$ \\
\hline 5 & $\mathrm{CS}$ mixed with $75 \%$ special liquid & $141^{\circ} \mathrm{C}$ \\
\hline
\end{tabular}

* Approximate values according to Ferreira et al.?

Table 3 - One-way ANOVA for marginal misfit.

\begin{tabular}{c|c|c|c|c|c}
\hline Source & $\begin{array}{c}\text { Sum of } \\
\text { squares }\end{array}$ & Df & $\begin{array}{c}\text { Mean } \\
\text { Square }\end{array}$ & F & Sig. \\
\hline Group & 1.114 & 4 & 0.278 & 21.0539 & $<.001$ \\
\hline Error & 0.463 & 35 & 0.013 & & \\
\hline
\end{tabular}

tion with $1 \% \mathrm{HF}$ and $13 \% \mathrm{HNO}_{3}$ for 10 min using the ultrasonic cleaner (Ultrasonic Cleaner, Odontobras, Ribeirão Preto, São Paulo, Brazil), and they were carefully examined for any irregularity and nodules.

The cast crowns were seated on the respective epoxy resin die and the marginal area was examined under a stereoscopic lens (Carl Zeiss, Jena, Turingia, Germany) at magnification of $10 \mathrm{X}$. The image of the misfit area was captured by a digital camera (JVC TK1380U CCD, Victor Company of Japan Limited, Tokyo, Kantô, Japan) in four points diametrically opposite around the die. The images were analyzed by the Leica QWin image analysis system (Leica Microsystems Imaging Solutions Ltd., Cambridge, East Anglia, England), and the marginal misfit $(\mu \mathrm{m})$ was measured by the same examiner using a contrast tool of the system. Three measurements were made for each point, yielding 12 measurements for crown, and the mean misfit was calculated.

One-way ANOVA and Tukey's HSD test were used to analyze the marginal misfit data $(\alpha=0.05)$.

The reaction layer in the casts, made into the investments prepared with different liquid concentration/casting temperatures, was assessed using Vickers hardness test. A piece of the sprue of each crown
Table 4 - Mean, standard deviation and mean contrast of marginal misfit $(\mu \mathrm{m})$.

\begin{tabular}{c|c}
\hline Group & Mean (SD) \\
\hline 1 & $459.1 \quad(87.7)^{c}$ \\
\hline 2 & $312.5 \quad(77.0)^{b}$ \\
\hline 3 & $495.7(157.6)^{c}$ \\
\hline 4 & $171.1 \quad(47.9)^{a}$ \\
\hline 5 & $346.0 \quad(54.9)^{b c}$ \\
\hline
\end{tabular}

used in the marginal misfit analysis was immersed in acrylic resin. The specimens were regularized with silicon carbide abrasive papers and polished with a felt disk and alumina paste in the Metaserv 2000 polishing machine (Buehler UK Ltd., Coventry, West Midlands, England). The Vickers hardness was measured in transverse section with the Micromet 2100 tester (Buehler Ltd., Lake Bluff, Illinois, USA), with a $300 \mathrm{~g}$ load and 15 seconds application time. The measurements were made at six depths from the sample surface to inner: at the surface, $50 \mu \mathrm{m}$, $100 \mu \mathrm{m}, 150 \mu \mathrm{m}, 200 \mu \mathrm{m}$ and $400 \mu \mathrm{m}$.

The two way ANOVA of the variables of the investment and depth of measurement was made. The Tukey's HSD test was used to detect statistical differences at the 0.05 level.

\section{Results}

The marginal misfit data were transformed using logarithmic transformation before parametric testing, to find homogeneity of variance. The one-way ANOVA (Table 3) showed significant differences among the investments $(\mathrm{P}<.001)$. The Tukey's test found that the castings made with Group 4 (CS $100 \% / 70^{\circ} \mathrm{C}$ ) had the lowest marginal misfit, followed by Group 2 (RE $100 \% / 237^{\circ} \mathrm{C}$ ). Group 1 (RP $\left.100 \% / 430^{\circ} \mathrm{C}\right)$ and Group $3\left(\operatorname{RE} 75 \% / 287^{\circ} \mathrm{C}\right)$ showed the highest marginal misfit. Group 5 (CS $75 \% / 141^{\circ} \mathrm{C}$ ) showed a mean statistically equal to Group 2, Group 1 and Group 3. The mean, standard deviation and mean contrast are presented in the Table 4.

The 2 way ANOVA of Vickers hardness (Table 5) showed that investment, depth and interaction between variation sources were significant $(\mathrm{P}>.001)$. The Tukey's test revealed that, in the depth com- 
Table 5 - Two-way ANOVA for titanium hardness.

\begin{tabular}{c|c|r|r|r|r}
\hline Source & Type II Sum of squares & Df & Mean Square & \multicolumn{1}{c}{$F$} & \multicolumn{1}{c}{ Sig. } \\
\hline Investment & 120321.526 & 4 & 30080.381 & 18.581 & $<.001$ \\
\hline Depth & 3480275.573 & 5 & 696055.155 & 429.962 & $<.001$ \\
\hline Interaction & 75599.325 & 20 & 3779.966 & 2.335 & .002 \\
\hline Error & 202359.629 & 125 & 1618.877 & & \\
\hline Total & 18294443.51 & 155 & & & \\
\hline
\end{tabular}

Table 6 - Mean, standard deviation and contrast of Vickers hardness (VHN).

\begin{tabular}{c|c|c|c|c|c|c}
\hline & surface & 50 & 100 & 150 & 200 & 400 \\
\hline G1 RP & $525.8^{\mathrm{Ba}}(64.8)$ & $388.8^{\mathrm{Bb}}(45.6)$ & $221.5^{\mathrm{Bc}}(20.5)$ & $192.5^{\mathrm{Bd}}(14.4)$ & $191.0^{\mathrm{Bd}}(16.1)$ & $188.5^{\mathrm{Bd}}(18.9)$ \\
\hline G2 RE 100 & $583.3^{\mathrm{Ba}}(71.4)$ & $365.6^{\mathrm{Bb}}(86.3)$ & $222.6^{\mathrm{Bc}}(50.5)$ & $205.1^{\mathrm{Bd}}(32.7)$ & $202.1^{\mathrm{Bd}}(22.4)$ & $192.8^{\mathrm{Bd}}(14.3)$ \\
\hline G3 RE 75 & $574.1^{\mathrm{Ba}}(91.6)$ & $364.7^{\mathrm{Bb}}(48.9)$ & $213.7^{\mathrm{Bc}}(39.8)$ & $181.7^{\mathrm{Bd}}(23.1)$ & $179.6^{\mathrm{Bd}}(18.1)$ & $173.2^{\mathrm{Bd}}(18.3)$ \\
\hline G4 CS 100 & $611.7^{\mathrm{Aa}}(70.0)$ & $447.9^{\mathrm{Ab}}(35.7)$ & $271.5^{\mathrm{Ac}}(34.0)$ & $217.1^{\mathrm{Bd}}(25.9)$ & $206.4^{\mathrm{Bd}}(18.1)$ & $204.0^{\mathrm{Bd}}(19.5)$ \\
\hline G5 CS 75 & $711.3^{\mathrm{Aa}}(39.7)$ & $495.2^{\mathrm{Ab}}(20.1)$ & $283.9^{\mathrm{Ac}}(30.8)$ & $224.4^{\mathrm{Bd}}(18.2)$ & $204.6^{\mathrm{Bd}}(12.4)$ & $207.8^{\mathrm{Bd}}(13.1)$ \\
\hline
\end{tabular}

Different uppercase letters indicate significant differences in columns $(P<.001)$. Different lowercase letters indicate significant differences in rows $(\mathrm{P}<.001)$.

parisons, the highest hardness mean value was at the surface (601.17 VHN), followed by $50 \mu \mathrm{m}$ depth (412.42 VHN) and $100 \mu \mathrm{m}$ depth (242.64 VHN). The hardness at depth $150 \mu \mathrm{m}(204.03 \mathrm{VHN})$ was similar to those at the $200 \mu \mathrm{m}(196.87 \mathrm{VHN})$ and $400 \mu \mathrm{m}$ (193.26 VHN) depths. The comparisons among the groups revealed that the Group 5 (CS $75 \%)$ had higher hardness than the other groups. Table 6 summarizes the interaction results with mean, standard deviation and contrast. The interaction results show that in regard to hardness there are no statistically significant differences among all groups at the $150 \mu \mathrm{m}, 200 \mu \mathrm{m}$ and $400 \mu \mathrm{m}$ depths.

\section{Discussion}

It is expected that phosphate-bonded investments would have a significant reaction layer, since $\mathrm{SiO}_{2}$ and $\mathrm{P}_{2} \mathrm{O}_{5}$ are reduced by titanium to form a $\mathrm{TiO}_{2}$ scale, whose layer thickness may reach $150 \mu \mathrm{m} .{ }^{6}$ From a clinical perspective, this contamination zone is undesirable because it interferes with mechanical properties and increases the surface roughness of the casting, resulting in an unsatisfactory fit of casting structures. ${ }^{6}$ To reduce this effect, a low mold temperature at the time of casting is recommended. ${ }^{6,10,11-14}$

The investment $\mathrm{CS}-100 \% / 70^{\circ} \mathrm{C}$ may have pre- sented the lowest marginal misfit due to its high setting expansion. For this material, the setting expansion alone was sufficient to reach an expansion equivalent to that of the control group. ${ }^{9}$ However, Morey $^{15}$ (1992) suggested that the setting expansion of the investment should be close to $0.05 \%$ in order to accommodate the wax expansion, and stated that the investment should have sufficient thermal expansion to compensate for casting shrinkage.

In addition, $\mathrm{RE}-100 \% / 237^{\circ} \mathrm{C}$ also presented significantly lower marginal misfit levels than the control group. This result is in agreement with the study by Takahashi et al. ${ }^{14}$ (1990) who reported a milder reaction layer and clinically acceptable marginal fit values.

However, the Vickers hardness test showed that the CS investment (75\% liquid concentration) had a higher reaction layer than the other groups (Table 6). Ferreira et al. ${ }^{9}$ (2007) affirm that the Castorit Super C has more relative content of cristobalite than Rema Exakt and Rematitan Plus, thus it would have thicker contamination layer. Takahashi et al. ${ }^{16}$ (1993) evaluated the effect of different phosphatebased investment compositions (quartz-based or cristobalite-based) and concluded that the cristobalite-based investments had significantly lower castability and higher surface hardness than those 
in molds using quartz as a refractory material.

It is possible that the temperatures increase the reaction layer thickness. ${ }^{6,12-14}$ Therefore, since the temperatures were low, it appeared that the reaction layer of the casting titanium with the CS $100 \%$ and RE $100 \%$ investment would be thinner than the RP that had the highest casting temperature $\left(430^{\circ} \mathrm{C}\right)$. A possible explanation could be supported by the investment compositions. Table 1 shows that the RP is the only one that has $\mathrm{Al}_{2} \mathrm{O}_{3}$ in its composition and has a lower $\mathrm{SiO}_{2}$ content than $\mathrm{RE}$ and CS. Although $\mathrm{Al}_{2} \mathrm{O}_{3}$ is an oxide that is reactive with titanium, it is less contaminant than $\mathrm{SiO}_{2} \cdot{ }^{17}$

In addition, the CS and RE investments showed high sensitivity to temperature increase. CS$75 \% / 141^{\circ} \mathrm{C}$ presented a marginal misfit statistically different than that of the CS- $100 \% / 70^{\circ} \mathrm{C}$. The RE$75 \% / 287^{\circ} \mathrm{C}$ showed marginal misfit $58 \%$ higher than $\mathrm{RE}-100 \% / 237^{\circ} \mathrm{C}$. We might speculate that the high reaction layer in the CS $75 \%$ interfered with the marginal fit. However, there was no statistical difference between the hardness of the RE 100\% and RE $75 \%$. Therefore, we cannot affirm that the reaction layer was the factor responsible for the higher misfit value of the RE $75 \%$.

Moreover, the effect of the mold temperature

\section{References}

1. Atwood RC, Lee PD, Curtis RV, Maijer DM. Modeling the investment casting of a titanium crown. Dent Mater. 2007 Jan;23(1):60-70.

2. Ohkubo C. The machinability of cast titanium and Ti-6Al-4V. Biomaterials. 2000 Feb;21(4):421-8.

3. Wang RR, Fenton A. Titanium for prosthodontic applications: a review of the literature. Quintessence Int 1996 Jun;27(6):4018.

4. Eliopoulus D, Zinelis S, Papadopoulos T. The effect of investment material type on the contamination zone an mechanical properties of commercially pure titanium castings. J Prosthet Dent. 2005 Dec;94(6):539-48.

5. Atwood RC, Lee PD, Curtis RV. Modeling the surface contamination of dental titanium investment castings. Dent Mater. 2005 Feb;21(2):178-86.

6. Papadopoulos T, Zinelis S, Vardavoulias M. A metallurgical study of the contamination zone at the surface of dental $\mathrm{Ti}$ castings, due to the phosphate-bonded investment material: should also be evaluated from another perspective. When there is a sharper difference between the casting temperature of pure titanium $\left(1,720^{\circ} \mathrm{C}\right)$ and the mold temperature, there is a very quick solidification of the molten titanium. Hence, there is not enough time for the mold margins to be effectively filled. ${ }^{6,18-}$ ${ }^{19}$ Incomplete margins may produce equally unacceptable results in terms of casting quality. ${ }^{6}$ Thus, further studies are required to assess the castability and porosity of titanium with the investments under the described conditions, which could be considered a limitation of the present study.

\section{Conclusion}

The low casting temperature investment Castorit Super $\mathrm{C}$ and Rema Exakt had better marginal fit than the special investment for titanium (Rematitan Plus). Therefore, the Castorit Super C and Rema Exakt showed sensitivity to temperature increase because the groups with $75 \%$ liquid concentration had worse fit and higher hardness than the group with $100 \%$ liquid concentration.

\section{Acknowledgments}

This study was supported by The São Paulo Research Foundation, Grant FAPESP: 2005/03105-1.

the protection efficacy of a ceramic coating. J Mater Sci. 1999 Aug;34:3639-46.

7. Hsu HC, Kikuchi H, Yen SK, Nishiyama M. Evaluation of different bonded investments for dental titanium casting. J Mater Sci Mater Med. 2005 Sep;16(9):821-5.

8. Low D, Mori T. Titanium full crown casting: thermal expansion of investments and crown accuracy. Dent Mater. 1999 May;15(3):185-90.

9. Ferreira AR, Adabo GL, Peitl Filho O, Rocha SS, Fonseca RG. Evaluation of the thermal shrinkage of titanium and the setting and thermal expansion of phosphate-bonded investments. J Prosthet Dent. 2007 Jul;98(1):24-9.

10. Wang RR; Welsch GE, Castro-Cedeno M. Interfacial reactions of cast titanium with mold materials. Int J Prosthodont. 1998 Jan-Feb;11(1):33-43.

11. Oda Y, Kudoh Y, Kawada E, Yoshinari M, Hasegawa K. Surface reaction between titanium castings and investments. Bull Tokyo Dent Coll. 1996 Aug;37(3):129-36. 
12. Morey EF. Dimensional accuracy of small gold alloy castings. Part 3. Gypsum-bonded investment expansion. Aust Dent J. 1992 Feb;37(2):43-54.

13. Ida K, Kuroda T, Otani H, Yamaga R. Studies on the casting of titanium alloy. Part I. Casting of pure titanium. J Res Soc Dent Mater Appl. 1980;37:45-52.

14. Lautenschlager E, Monaghan P. Titanium and titanium alloys as dental materials. Int Dent J. 1993 Jun;43(3):245-53.

15. Takahashi J, Kimura H, Lautenschlager EP, Chern Lin JH, Moser JB, Greener EH. Casting pure titanium into commercial phosphate-bonded $\mathrm{SiO}_{2}$ investments molds. J Dent Res. 1990 Dec;69(12):1800-5.

16. Takahashi J, Zhang JZ, Okazaki M. Castability and surface hardness of titanium cast plates obtained from experimental phosphate-bonded silica investment molds. Dent Mater J. 1993 Dec;12(2):238-44.

17. Mori T, Jean-Louis M, Yabugami M, Togaya T. The effect of investment type on the fit of cast titanium crowns. Aust Dent J. 1994 Dec;39(6):648-52.

18. Miyakawa O, Watanabe K, Okawa S, Nakano S, Kabayashi M, Shiokawa N. Layered structure of cast titanium surface. Dent Mater J. 1989 Dec;8(2):175-85.

19. Oliveira PCG, Adabo GL, Faria RR, Rocha SS. The effect of mold temperature on castability of CP Ti and Ti-6Al-4V castings into phosphate-bonded investment materials. Dent Mater. 2006 Dec;22(12):1098-102. 